\title{
ETHICAL ASSESSMENT MANAGER AGAINST A CONFLICT OF INTEREST THE CORPORATE SOCIAL
}

\author{
Inova Fitri Siregar \\ Universitas Lancang Kuning \\ siregar_inovafitri@yahoo.com
}

\begin{abstract}
The idea of social responsibility or known as Corporate Social Responbility ( CSR) is getting widely accepted.Group that supports discourse social responsibility of the opinion that the company cannot be separated from individuals who involved in this, namely the owner and employees. But they should not just think of profit $f$, but also must have sensitivity and concern for public. With the csr activity conducted by the company manager, and has budgeted by the a company so create conflicts of interest.The purpose of this research is to analyze how assessment ethical manager to conflict an interest in the activity of their Sample used is all employers who engaging in activities corporate social responsibility as many as 30 companies located in pematang pudu sub district mandau.The result that has been achieved are the judgments ethical manager to a conflict of interest has been included in four criteria: from the benefits, justice, fulfilling the right and maintenance, but each company should have alternative how minimize pressure from the public so that not avoid activity CSR
\end{abstract}

Key Word: Manager Ethic, Conflict of Interest and Corporate Social Responsibility

\section{PENDAHULUAN}

Dalam konteks pembangunan saat ini, perusahaan tidak lagi dihadapkan pada tanggungjawab yang berpijak pada aspek keuntungan secara ekonomis semata, yaitu nilai perusahaan yang direfleksikan dalam kondisi keuangan, namun juga harus memperhatikan aspek sosial dan lingkungannya. Perusahaan bukan lagi sekedar kegiatan ekonomi untuk menciptakan profit demi kelangsungan usahanya, melainkan juga bertanggungjawab terhadap aspek sosial dan lingkungannya. Dasar pemikirannya adalah menggantungkan semata-mata pada kesehatan finansial tidak menjamin perusahaan bisa tumbuh secara berkelanjutan (sustainable). Keberlanjutan akan terjamin apabila perusahaan memperhatikan aspek terkait lainnya, yaitu aspek sosial dan lingkungan (Rudito dkk., 2004).

Ide mengenai Tanggung jawab Sosial atau yang dikenal dengan Corporate SocialResponbility (CSR) kini semakin diterima secara luas. Kelompok yang mendukung wacana tanggung jawab sosial berpendapat bahwa perusahaan tidak dapat dipisahkan dari para individu yang terlibat didalamnya, yakni pemilik dan karyawannya. Namun mereka tidak boleh hanya memikirkan keuntungan finansialnya saja, melainkan pula harus memiliki kepekaan dan kepedulian terhadap publik.Dengan adanya aktivitas tanggung jaawab sosial 
yang dilakukan oleh para manager perusahaan, dan telah dianggarkan oleh pihak perusahaan sehingga menimbulkan konflik kepentingan. Perusahaan bertanggung jawab atas pemangku kepentingan yang membuat keputusan untuk kepentingan perusahaan, tanpa mempertimbangkan kepentingan pribadi. Konflik kepentingan dapat timbul apabila penilaian dapat dipengaruhi untuk kepentingan pribadi. Penelitian ini berupaya mencari tahu bagaimana penilaian etis manager terhadap konflik kepentingan atas aktivitas CSR?. Dengan

\section{TELAAH TEORETIS}

Perkembangan CSR tidak bisa terlepas dari konsep pembangunan berkelanjutan (sustainability development), definisi pembangunan berkelanjutan menurut The World Commission On Environment and Development yang lebih dikenal dengan The Brundtland Comission, bahwa pembangunan berkelanjutan adalah pembangunan yang dapat memenuhi kebutuhan manusia saat ini tanpa mengorbankan kemampuan generasi yang akan datang dalam memenuhi kebutuhan mereka (Solihin: 2009). The Brundtland Comission dibentuk untuk menanggapai keprihatinan yang semakin meningkat dari para pemimpin dunia terutama menyangkut peningkatan kerusakan lingkungan hidup dan sumber daya alam yang semakin cepat. Selain itu komisi ini juga dibentuk untuk mencermati dampak kerusakan lingkungan hidup dan sumber daya alam terhadap ekonomi dan pembangunan sosial. Oleh karenanya, konsep sustainability development dibangun diatas tiga pilar yang berhubungan dan saling mendukung satu dengan lainnya, Ketiga pilar tersebut adalah sosial, ekonomi, dan lingkungan, sebagaimana ditegaskan kembali dalam The United Nation 2005 World Summit Outcome Document (Solihin: 2009).

Hubungan keagenan merupakan suatu kontrak dimana satu atau lebih orang (prinsipal) memerintah orang lain (agen) untuk melakukan suatu jasa atas nama prinsipal serta memberi wewenang kepada agen membuat keputusan yang terbaik bagi prinsipal. Jika kedua belah pihak tersebut mempunyai tujuan yang sama untuk memaksimumkan nilai perusahaan, maka diyakini agen akan bertindak dengan cara yang sesuai dengan kepentingan prinsipal. Masalah keagenan potensial terjadi apabila bagian kepemilikan manajer atas saham perusahaan kurang dari seratus persen (Masdupi, 2005). Dengan proporsi kepemilikan yang hanya sebagian dari perusahaan membuat manajer cenderung bertindak untuk kepentingan pribadi dan bukan untuk memaksimumkan perusahaan. Inilah yang nantinya akan menyebabkan biaya keagenan (agency cost). Jensen dan Meckling (1976) mendefinisikan agency cost sebagai jumlah dari biaya yang dikeluarkan prinsipal untuk melakukan pengawasan terhadap agen. Hampir 
mustahil bagi perusahaan untuk memiliki zero agency cost dalam rangka menjamin manajer akan mengambil keputusan yang optimal dari pandangan shareholders karena adanya perbedaan kepentingan yang besar diantara mereka.

Etika adalah padangan, keyakinan, dan nilai akan sesuatu yang baik dan buruk, benar dan salah. Etika manajerial merupakan sandar perilaku yang memandu manajer dalam pekerjaan mereka. Griffin (2013) mengklasifikasikan etika manajerial ke dalam tiga kategori, yaitu: (1) Perilaku terhadap karyawan; (2) Perilaku terhadap organisasi, (3) Perilaku terhadap agen ekonomi.

\section{METODE}

Lokasi penelitian adalah orang atau peristiwa yang sedang diteliti. Adapun yang menjadi objek dalam penelitian ini adalah Perusahaan yang terlibat dalam kegiatan Corporate Social Responsibility yang masuk dalam kelompok gabungan pengusaha suku sakai dikecamatan Mandau Kabupaten Bengkalis. Populasi adalah sekelompok orang, kejadian atau segala sesuatu yang mempunyai karakteristik tertentu sedangkan sampel adalah sebagian dari elemen populasi (Indriantoro dan Supomo: 2002:15). Menurut Sugiyono (2005), sampel adalah sebagian dari jumlah dan karakteristik yang dimiliki oleh suatu populasi. Populasi dalam penelitian ini adalah seluruh Perusahaan yang terlibat dalam kegiatan Corporate Social Responsibility yang masuk dalam kelompok gabungan pengusaha suku sakai di Kecamatan Mandau Kabupaten Bengkalis

Teknik pengambilan sampel dalam penelitian ini adalah metode random sampling. Metode tersebut merupakan pemilihan sampel dimana populasi yang akan dijadikan sampel yang dikehendaki oleh peneliti sesuai dengan tujuan penelitian (Ghazali: 2006). Dengan mempertimbangkan arah dan tujuan penelitian, kriteria yang ditetapkan adalah:

a. Perusahaan yang diteliti adalah perusahaan yang terlibat dalam kegiatan Corporate Social Responsibility yang masuk dalam kelompok gabungan pengusaha suku sakai dikecamatan Mandau Kabupaten Bengkalis.

b. Perusahaan yang menyajikan laporan keuangan secara lengkap

Dengan memperhatikan kriteria di atas, dipilih keseluruhan populasi yang diambil berjumlah 30 Perusahaan yang terlibat dalam kegiatan Corporate Social Responsibility yang masuk dalam kelompok gabungan pengusaha suku sakai di kecamatan Mandau Kabupaten Bengkalis sebagai sampel penelitian. 
Data yang digunakan dalam penelitian ini adalah data sekunder, yaitu data yang diperoleh dari pihak lain berupa kuesioner. Data yang digunakan dalam penelitian ini berupa kuesioner dari perusahaan yang terlibat dalam kegiatan Corporate Social Responsibility yang masuk dalam kelompok gabungan pengusaha suku sakai dikecamatan Mandau Kabupaten Bengkalis sebagai sampel penelitian

Analisis data adalah proses penyederhanaan data ke dalam bentuk yang mudah dibaca dan diinterpretasikan. Dalam mengolah dan menganalisis data digunakan analisis dan pengujian kuantitatif. Analisis kuantitatif menyangkut pengolahan data dengan menggunakan rumus-rumus yang dapat diterapkan untuk menganalisis data. Tujuan dari analisis ini adalah untuk mendapatkan informasi yang relevan yang terkandung dalam data tersebut dan menggunakan hasilnya untuk memecahkan suatu masalah. Metode analisis data yang digunakan dalam penelitian ini adalah metode analisis deskriptif

\section{HASIL DAN PEMBAHASAN}

Terdapat 30 perusahaan yang diperoleh pendapatnya mengenai bagaimana perilaku etis seorang manajer. Penelitian Etis dan Konflik Kepentingan memiliki makna strategis yakni pemerolehan manfaat, pemenuhan hak semua pihak berkepentingan, bernilai keadilan bagi semua pihak, keberlansungan tindakan berwawasan lingkungan. Tabel 1 menunjukan rekapitulasi penyampelan yang diperoleh di lapangan. Pada tabel diatas dapat disimpulkan bahwa responden menjawab pertanyaan bahwa perusahaan perlu memiliki tanggung jawal sosial dan beranggapan bahwa banyak persoalan di masyarakat muncul sebagai akibat dari kegiatan perusahaan yang dijalankan sebanyak 30 orang atau sebesar $100 \%$.

Hasil pertanyaan bagaimana tanggung jawabsosial yang harus dipikul perusahaan tidak perlu terlibat dalam tanggung-jawab social sebanyak 20 orang atau sebanyak 66,67\%, hal ini dikarenakan pada dasarnya perusahaan tidak memiliki ahli-ahli khusus untuk menangani tanggung-jawab social ini dalam perusahaan.

Kemudian dilanjutkan dengan pertanyaan yang berkaitan dengan apakah perusahaan menghindari adanya aktivitas sosial , dimana responden yang menjawab setuju atas pertanyaan tersebut sebanyak 13 orang $43,3 \%$, hal tersebut terjadadi sedikit tidaknya para manajer mengetahui tanggungjawabsosial yang dilakukan oleh perusahaan terkait dengan penggunaan pendekatan legal atau jalur hokum untuk menghindarkan diri atau menolak tanggung jawab-sosial. Pertanyaan terakhir dimana perusahaan mengambil inisiatif dalam aktivitas dan membuat suatu pengalokasian biaya CSR sebanyak 15 orang menanggapan 
benar atau 50\% , hal ini disimpulkan bahwa tanggung jawab social adalah bagian dari tanggung jawab untuk memuaskan stakeholders.

\begin{tabular}{|l|l|c|c|}
\hline No & Pertanyaan & Ya & Tidak \\
\hline 1 & Perilaku Organisasi & & \\
\hline 2 & $\begin{array}{l}\text { Perusahaan adalah bagian dari lingkungan sosial masyarakat, oleh karena } \\
\text { itu oleh karena itu semestinya ikut berpartisipasi dan bertanggungjawab }\end{array}$ & $66,67 \%$ & $33,3 \%$ \\
\hline & $\begin{array}{l}\text { Kegiatan bisnis kerap terjadi masalah, perusahaan seharusnya } \\
\text { bertanggungjawab atas yang terjadi }\end{array}$ & $100 \%$ & $0 \%$ \\
\hline 3 & Manajer perusahaan mempunyai pengetahuan atas tanggungjawab sosial & $30 \%$ & $70 \%$ \\
\hline 1 & Perilaku Karyawan & & \\
\hline 2 & $\begin{array}{l}\text { Perusahaan tidak mempunyai tenaga ahli dalam bidang sosial dan } \\
\text { kemasyarakatan }\end{array}$ & $100 \%$ & $0 \%$ \\
\hline 3 & $\begin{array}{l}\text { Manajermemberikaninsentifkepadapegawai yang berprestasi } \\
\text { lebihmemenuhisyarat }\end{array}$ & $66,67 \%$ & $33,3 \%$ \\
\hline 1 & Konflik Kepentingan atas Aktivitas CSR & $0 \%$ & $100 \%$ \\
\hline 2 & $\begin{array}{l}\text { terlibat dalam aktivitas sosial } \\
\text { Perusahaan melakukan aktivitas sosial karena mengetahui pentingnya CSR }\end{array}$ & $100 \%$ & $0 \%$ \\
\hline 3 & $\begin{array}{l}\text { Perusahaan melakukan aktivitas CSR untuk meminimalisir tekanan dari } \\
\text { masyarakat }\end{array}$ & $53,3 \%$ & $46,6 \%$ \\
\hline 4 & Perusahaan cenderung menghindari aktivitas sosial & $43,3 \%$ & $56,6 \%$ \\
\hline 5 & $\begin{array}{l}\text { Perusahaan mengambil inisiatif dalam aktivitas dan membuat suatu } \\
\text { pengalokasian biaya CSR }\end{array}$ & $50 \%$ & $50 \%$ \\
\hline
\end{tabular}

Tabel 2.

\section{Hasil Rekapitulasi Penilaian Etis Manajer terhadap Konflik Kepentingan atas Aktivitas CSR}

Nilai personal dapat digunakan untuk mengukur etika. Lebih lanjut lagi, Griffin (2000) mengenalkan sebuah model untuk menilai etika. Model penilaian etika tersebut memberikan panduan apakah sesuatu tindakan atau kegiatan memenuhi criteria atau tida kdapat dinilai dari 4 kriteria etika, yaitu dari sisi manfaat (benefits), pemenuhan hak-hak (rights), prinsip keadilan(justice), dari sifat pemeliharaan(caring). Hasil rekapitulasi kuesioner yang telah disebarkan atas pertanyaan pentingnya seorang manajer berpartisipasi dalam aktivitas sosial, bagaimana tanggungjawab perusahaan dan dikoordinasikan oleh seorang manajer apabila terjadi suatu masalah dan bagaimana manajer mempunyai pengetahuan mengenai tanggungjawab sosial dapat disimpulkan telah masuk dalam 4 kriteria dilihat dari sisi manfaat, pemenuhan hak, prinsip keadilan dan sifat pemeliharaan,

Konsep CSR yang perpedoman kepada Triple Bottom Line dimana perusahaan harus menyeimbangkan aktivitas lingkungan, sosial dan ekonomi, dimana pada saat ini kebanyakan 
perusahaan hanya berorientasi pada laba semata, hal ini terjadi mungkin tidak hanya dipahami oleh semua manajer, hal ini yang menjadi masalah, keterbatasan pengetahuan, sehingga akan menimbulkan konflik , baik konflik dari masyarakat maupun konflik terhadap internal perusahaan, manajer akan beranggapan bahwa mereka akan mengeluarkan dana aktivitas CSR karena adanya tekanan dari masyarakat, kemudian akan berakhir pada menghindari adanya aktivitas CSR.

Dari hasil responden, masuk dalam 4 kriteria dilihat dari sisi manfaat, pemenuhan hak, prinsip keadilan dan sifat pemeliharaan, akan tetapi pada pertanyaan perusahaan cenderung menghindari adanya aktivitas CSR sebanyak dari 30 responden hanyak 43,3\% dan perusahaan melakukan aktivitas CSR bertujuan untuk meminimalisir tekanan dari masyarakat sebanyak 16 orang atau 53,3\%, hal ini terjadi disebabkan karena kurangnya pemahaman mereka terhadap konsep dari CSR dan bagaimana mengaplikasi sehingga mereka tidak akan berasumsi bahwa masyarakat menjadi penyebab perusahaan harus melakukan aktivitas sosial tersebut. Hal tersebut dibuktikan pada saat observasi dan wawancara pada responden yang terdapat di daerah Duri, perusahaan harus mengeluarkan aktivitas CSR dikarenakan adanya tekanan dari masyarakat, contohnya masyarakat meminta pekerjaan dan mengancam beberapa pegawai untuk diminta dalam hal finansial. Dengan demikian dengan adanya kejadian tersebut, akan menjadikan seorang manager akan berperilaku tidak etis sehingga akan menimbulkan penghindaraan aktivitas CSR

Rencana tahapan berikut setelah penelitian ini dilakukan adalah akan melanjutkan upaya apa yang harus dilakukan oleh perusahaan, sehingga bisa menjalankan aktivitas perusahaan tanpa mengabaikan konsep Triple Bottom Line. Dan tidak hanya untuk perusahaan-perusahaan yang terdapat dikabupaten bengkalis saja, karena pada saat ini, banyak perusahaan yang melakukan aktivitas yang langsung berhubungan dengan masyarakat dan akan berpengaruh terhadap lingkungan.

\section{KESIMPULAN}

Perusahaan cenderung menghindari adanya aktivitas CSR sebanyak dari 30 responden hanyak 43,3\% dan perusahaan melakukan aktivitas CSR bertujuan untuk meminimalisir tekanan dari masyarakat sebanyak 16 orang atau 53,3\%, hal ini terjadi disebabkan karena kurangnya pemahaman mereka terhadap konsep dari CSR dan bagaimana mengaplikasi sehingga mereka tidak akan berasumsi bahwa masyarakat menjadi penyebab perusahaan harus melakukan aktivitas sosial tersebut. Hal tersebut dibuktikan pada saat observasi dan 
wawancara pada responden yang terdapat di daerah duri, perusahaan harus mengeluarkan aktivitas CSR dikarenakan adanya tekanan dari masyarakat, contohnya masyarakat meminta pekerjaan dan mengancam beberapa pegawai untuk diminta dalam hal finansial. Dengan demikian dengan adanya kejadian tersebut, akan menjadikan seorang manager akan berperilaku tidak etis sehingga akan menimbulkan penghindaraan aktivitas CSR.

\section{DAFTAR PUSTAKA}

Damayanti, D., \& Pentiana, D. (2018). Global Warming" in the Perspective of Environmental Management Accounting (EMA). Jurnal Ilmiah ESAI, 7(1).

Griffin, R. W. (2013). Fundamentals of management. Cengage Learning.

Ghozali, I. (2006). Aplikasi analisis multivariate dengan program SPSS. Badan Penerbit Universitas Diponegoro.

Hansen, D. R., \& Mowen, M. M. (2007). Managerial accounting 8 th edition: USA: Thomson South Western.

Ikhsan, Arfan.2008.Akuntansi Lingkungan Dan Pengungkapannya. Graha Ilmu: Yogyakarta

Indriantoro, N., \& Supomo, B. (1999). Metodologi Penelitian Bisnis untuk Akuntansi \& Manajemen. edisi pertama. Yogyakarta: BPFE-YOGYAKARTA.

Indonesia, I. A. (2009). Standar akuntansi keuangan.

Jensen, M. C., \& Meckling, W. H. (1976). Theory of the firm: Managerial behavior, agency costs and ownership structure. Journal of financial economics, 3(4), 305-360.

Mathews, M. R. (2000). The development of social and environmental accounting research 1995-2000.

Martusa, R. (2011). Peranan Environmental Accounting terhadap Global Warming. Jurnal Akuntansi Maranatha, 1(2), 164-179.

Masdupi, E. (2005). Analisis dampak struktur kepemilikan pada kebijakan hutang dalam mengontrol konflik keagenan. Jurnal Ekonomi dan Bisnis Indonesia, 20(2005).

Sari, Susiana, Sudjana, Nengah dan Azizah, Devi Farah. 2013. Penerapan Akuntansi Lingkungan Untuk Mengoptimalkan Tanggung Jawab Industri Gula: (Studi Pada PT Perkebunan Nusantara X Unit Pabrik Gula Lestari Nganjuk). Jurnal Administrasi Bisnis (JAB)|Vol. 2 No. 1 Mei 2013|

Sahasrakirana, G. W. (2012). Evaluasi Peran Akuntansi Lingkungan Untuk Mendukung Keputusan Manajemen Lingkungan Pada PT Sahabat Mewah Dan Makmur (Anj Agri Belitung) Dalam Rangka Mencapai Sustainability Perusahaan (Doctoral dissertation, Thesis S1 Tidak Dipublikasikan, Universitas Bina Nusantara, Jakarta).

Sugiyono, Y. (2005). Analisis Statistika-Korelasi Linier Sederhana.

Yakhou, M., \& Dorweiler, V. P. (2004). Environmental accounting: an essential component of business strategy. Business Strategy and the Environment, 13(2), 65-77. 